ks. Krzysztof Guzowski

Katolicki Uniwersytet Lubelski Jana Pawła II

DOI: $10.15290 /$ std.2017.03.03

\title{
NADZWYCZAJNOŚĆ I NOWOŚĆ W RUCHU ODNOWY CHARYZMATYCZNEJ. CO JEST DAREM DUCHA ŚWIĘTEGO, A CO KREACJA CZŁOWIEKA?
}

\section{EXTRAORDINARINESS AND NOVELTY IN THE CHARISMATIC RENEWAL MOVEMENT. HOW TO TELL THE GIFT OF THE HOLY SPIRIT FROM MAN'S CREATION?}

The Charismatic Renewal movement, in whose wake a number of evangelizing communities of prayer and new religious congregations have appeared, is nowadays identified with what is unusual - with extraordinary forms of devotion and the like phenomena. The author reminds us that 50 years ago, which is exactly when the movement began to unfold, it was perceived as one of the most significant signs of the New Pentecost, or the Holy Spirit's intensified work in our times. Paul VI and the subsequent popes pointed to the Holy Spirit's "intensified activity", deeming Him to be the Reviver of the Church and the Font of the world's new life. Alas, the mighty presence in question, as well as the Holy Spirit's intensified activity in the Church, have been overshadowed by, on the one hand, ever-increasing focus on the part of the members of the movement under scrutiny on what in the first place satisfies the needs of people, i.e. healing and unusual phenomena; and, on the other hand, by the excessive scepticism of theologians and pastors, who for the 50 years of the Renewal existence have not equipped the faithful, unable to tell the essence from the unusualness, with their theological reflection. The author pays attention to the fact that the categories of "ordinary" and "extraordinary" with regard to the New Pentecost do not put anything in order, but, subjective as 
they are, they hinder the theological reflection itself. Thus, he suggests that we focus on the differentiation of what is the Holy Spirit's gift from what is man's creation. In the article he compares from this point of view two "ordinary" areas of the Holy Spirit's activity - the baptism in the Holy Spirit and contemplative prayer. By doing so, Guzowski proves that the emphasis on the person of the Holy Spirit and His work of sanctification allows us to tell the essence of the New Pentecost from secondary issues.

Key words: the Holy Spirit, New Pentecost, Charismatic Renewal movement, baptism in the Holy Spirit, contemplative prayer, ordinary, extraordinary.

„Bóg nie kocha nas miłością zwyczajną. Nie, nadzwyczajna miłość jest właściwa istocie Boga".

W ramach teologii pewne kategorie subiektywne zadomowily się na tyle, że urosły do rangi niekwestionowanych kryteriów oceny tego, co normalne, a co poza normalnym biegiem rzeczy. Do takich należy rozróżnienie na zwyczajne i nadzwyczajne, w świetle którego zwykło się wyznaczać linię demarkacyjną między codziennością i nadzwyczajnością dla działań Ducha Świętego. Ba! podkreślanie zwyczajnej i codziennej obecności Ducha Świętego w naszym porządku doczesnym, jest dziś traktowane nierzadko, jako coś nowego. Natomiast w świetle teologii paschalnej pierwszorzędnym skutkiem Pięćdziesiątnicy jest stała obecność Ducha Świętego. Całe dzieło Odkupienia trwa i się rozwija w ludziach, w Kościele i w świecie dzięki Jego przebóstwiającej obecności ${ }^{1}$.

Nietrudno zauważyć, że działalność od pięćdziesięciu lat Odnowy Charyzmatycznej w Kościele katolickim, nie uprościła kwestii podziału na zwyczajność i nadzwyczajność działań Ducha Świętego oraz Jego nieprzerwanej obecności w naszej codzienności. Duch Święty - ku zawstydzeniu teologów i duszpasterzy - jest nadal „tematem” nadzwyczajnym, wyjątkowym, drugorzędnym... Pięćdziesiątnica, która była początkiem potężnego zstąpienia Boga w Duchu Świętym i wylania się Bożej mocy na świat - na podobieństwo oceanu zstępującego $z$ nieba ku ziemi - istnieje zaledwie w umysłach jako wydarzenie z przeszłości. Dlatego pilnym zadaniem teologów jest przywrócenie owej dynamicznej wizji Zesłania Ducha Świętego, który od tamtego wydarzenia udziela

$1 \quad$ Por. E. Carter, Duch Święty jest obecny. Rozważania o duchowości chrześcijańskiej, tł. A. Korlińska, Warszawa 1975; R. Del Colle, The Holy Spirit: Presence, Power, Person, „TheologicalStudies” 62(2001), s. 322-340; R. Cantalamessa, Tajemnica Pięćdziesiątnicy, tł. G. Niedźwiedź, Wrocław 2002; P. Hocken, Pięćdziesiątnica i Paruzja, tł. A. Sionek, Kraków 2015. 
hojnie przeobfitych darów Bożego życia. Pięćdziesiątnica jest wydarzeniem trynitarnym, które miało swój moment Alfa, ale które trwa i rozlewa się na cały świat poprzez sakramenty, charyzmaty, głoszenie Słowa i wszelkie dzieła miłości na wzór miłości ukrzyżowanej Jezusa² .

Nie należy przeceniać ewentualnych wyników uporządkowania i zobiektywizowania kategorii „zwyczajności” i „nadzwyczajności”, gdyż istotniejsze dla podstaw wiary będzie odróżnienie tego, co jest darem Ducha, a co wytworem człowieka. Ale dobrze jest zachować w świadomości, że „nie jesteśmy wolni od pokusy mówienia o dwóch rodzajach doświadczenia: zwyczajnym i nadzwyczajnym. Jest to rozróżnienie na naszą miarę, według której spotkanie z Bogiem wydaje się nam czymś niecodziennym, nieoczekiwanym, jedynym w swoim rodzaju, poza normalnym biegiem rzeczy. (...) Ale nie jest to rozróżnienie na miarę Boga. (...) Bóg nie kocha nas miłością zwyczajną, od której czyniłby czasem wyjątek przez gest miłości nadzwyczajnej, nadmiernej. Nie, nadzwyczajna miłość jest właściwa istocie Boga: nasz Bóg jest Bogiem prawdziwym, w cudowny sposób miłującym ludzi”’3.

Próba zarysowania owej różnicy pomiędzy tym, co jest darem Ducha a co wytworem człowieka, ma jedynie służyć zbliżeniu do Boga, Ducha Świętego, którego miłości możemy doświadczyć na co dzień w żywej komunii Kościoła. Teologia nigdy nie miała ambicji, by teoretycznymi rozważaniami nad prawdami wiary, oddzielić się od żywego doświadczenia spotkania z Osobami Trójcy, opartymi na wierze i miłości. Z tego względu, by uniknąć wyobrażenia, iż Duch Święty jest ograniczony formami duchowości charyzmatycznej lub kontemplacyjnej, wybraliśmy dla porównania dwa typowe dzieła Ducha Świętego: chrzest w Duchu Świętym oraz modlitwę kontemplacyjna, które należą do istotnych wkładów wspólnot zrodzonych w obrębie ruchu Odnowy Charyzmatycznej. Jedno przychodzenie Ducha pełne mocy, drugie - łagodne, są obrazami dynamicznej obecności Ducha Świętego po Pięćdziesiątnicy. Dzięki temu porównaniu łatwiej będzie nam połączyć obrazy charyzmatycznego i uświęcającego wymiaru życia chrześcijańskiego, w jeden ${ }^{4}$.

2 ICCRS, Chrzest w Duchu Świętym, Kraków 2014, s. 28-34. (ICCRS - skrót od angielskiej nazwy Międzynarodowej Służby Katolickiej Odnowy Charyzmatycznej).

3 L. J. Suenens, Nowe Zesłanie Ducha Świętego? tł. J. Fenrychowa, Poznań 1988, s. 67.

$4 \quad$ Por. L. M. Örsy, Otwarcie się na Ducha, tł. T. Marcinkowska, Warszawa 1976, s. 146-178. 


\section{Pięćdziesiątnica to obecność i napełnienie}

Następstwem i skutkiem Pięćdziesiątnicy jest aktywna wszechobecność Ducha Świętego ${ }^{5}$. Nie jest to jedyna nowość Pięćdziesiątnicy, gdyż od początku istnienia świata Duch Boży przenikał na sposób immanentny świat stworzony, zwłaszcza byty duchowe. Nowością jest to, że jest ona wydarzeniem paschalnym: odnowiona przez Chrystusa natura ludzka, stała się zdolną do przyjęcia Ducha i do życia poddanego Bogu w wolności. Dary Ducha właściwe tylko Mesjaszowi stały się powszechnymi darami dla ludzi, a oni po napełnieniu obecnością Ducha stali się Jego świątyniami. Ta trwała i dynamiczna obecność przebóstwiająca stała się właśnie treścią odnowionego życia w Duchu. Człowiek został włączony przez Ducha Świętego w życie samego Chrystusa, jak winna latorośl w pień winnego krzewu ${ }^{6}$.

Księga Dziejów Apostolskich, ukazuje Ducha Świętego jako źródło i siłę rozwoju Kościoła. Księgę Dziejów można z równym powodzeniem nazwać ewangelią Kościoła Pięćdziesiątnicy, jak i Ewangelią Ducha Świętego: od pierwszego momentu, kiedy Chrystus obiecuje Go Apostołom (Dz 1, 5), aż do końca, kiedy Paweł odwołuje się do Ducha, obwiniając współwyznawców o zatwardziałość serc $(\mathrm{Dz} 28,25)$. Do charakterystycznych cech działania Ducha Świętego opisanych w Dziejach Apostolskich, należy bezpośredniość interweniowania w konkretne wydarzenia. Duch Święty działa w pierwszej osobie, sam podejmuje działania, co zwraca uwagę na Jego osobowy charakter: „rzekł Duch Święty” (13, 2); „wysłani przez Ducha Świętego” (13, 4). Ów charakterystyczny sposób działania widoczny jest zwłaszcza w drugiej części Dziejów Apostolskich, począwszy od 13 rozdziału? ${ }^{7}$ Nawet wówczas, gdy mówi

5 Problematyka obecności Osób Trójcy Świętej domagałaby się osobnego wyjaśnienia. Oczywiste jest, że żadna z Osób Trójcy nie działa w oddzieleniu od pozostałych, dlatego nasze skupienie na analizie form obecności Ducha Świętego, nie powinno być traktowane jako forma propagowania pneumatocentryzmu. Odsyłamy w tym miejscu do stosownych opracowań. Por. Y. Congar, Wierzę w Ducha Świętego, t. 2, tł. L. Rutowska, Warszawa 1995, s. 109-118.

6 Bliskie autorowi są inspiracje Ojców greckich, co do wyjaśnienia sposobów udzielania się Osób Boskich człowiekowi. Jednakże o wiele większą jasność, co do osobowych znamion udzielania się Trójcy, znajdziemy w nowszych schematach trynitarnych, takich autorów, jak: G. Greshake, W. Kasper i J. Moltmann. Z myślicieli starożytnych zacytujmy przynajmniej św. Atanazego: „Ojciec czyni wszystko przez Słowo w Duchu Świętym i w ten sposób zachowana zostaje jedność Świętej Trójcy (...). Rzeczywiście, podobnie jak udzielana łaska przychodzi od Ojca, przez Syna, tak udzielanie nam daru może się dokonać jedynie w Duchu Świętym, ponieważ uczestnicząc w Nim mamy miłość Ojca, laskę Syna i dar jedności tegoż Ducha Świętego (2 Kor 13, 13)”; por. Ad Serapionem I, 28 i 30. Cyt. za Y. Congar, s. 116.

7 Por. R. E. Brown, Azione e promessa dello Spirito a Pentecoste, Brescia 1995, s. 118-124; (Dz 13, 2.4; 16, 6-10; 20, 22.23.28; 21, 4.11). 
się o działaniu człowieka, to pozostaje ono pod wpływem Ducha Świętego. W części pierwszej Dziejów przeważają natomiast teksty traktujące o działaniu ludzi pod wpływem Ducha Świętego, ale i tu pierwszeństwo przypisane jest Duchowi Świętemu jako podmiotowi działania zbawczego ${ }^{8}$.

Duch Święty jest bez wątpienia darem eschatologicznym na wszystkie czasy Kościoła, wyraża się to w zadaniu misyjnym głoszenia Chrystusa, aż po krańce (eschaton) ziemi w mocy Ducha Świętego. Jest to nieustannie poświadczane, począwszy od obietnicy złożonej przez Jezusa, którą zaczyna się księga: „Gdy Duch Święty zstąpi na was, otrzymacie Jego moc i będziecie moimi świadkami (...) aż po krańce ziemi" $(1,8)$, a skończywszy na ostatnim świadectwie św. Pawła (por. 28, 31). Dzieje Apostolskie są świadectwem, iż wiara Kościoła w stałą obecność i prowadzenie przez Ducha Świętego stanowiła główny element życia i misji. Ducha Świętego nie tylko wzywano w nadzwyczajnych momentach misji Kościoła, gdyż był On Duchem Chrystusa, dzięki któremu dzieło Zbawienia się szerzyło w duszach ludzi. Modlitwa do Ducha Świętego, wołanie o to, by objawiała się Jego obecność i władza nad światem, należy do zwyczajnego porządku wiary chrześcijańskiej ${ }^{9}$.

Trudno nie zauważyć, iż kategorie zwyczajności i nadzwyczajności w kontekście daru Pięćdziesiątnicy (tj. daru Ducha Świętego) nie są adekwatne dla opisania tajemnicy przeobfitej miłości Boga, który we wszystkich dziełach jest hojny. Najbardziej zdumiewające akty Jego miłości - Wcielenie, Krzyż, Eucharystia, Pięćdziesiątnica - przekraczają wszelkie granice ludzkiego wyrachowania, a nawet najśmielsze wyobrażenia ${ }^{10}$. Cecha nadzwyczajności może się jedynie odnosić do form nabożeństw lub praktyk modlitewnych, które - jako dzieła ludzkie - nie zawsze zachowują umiar i harmonię ${ }^{11}$.

Na początku XX wieku chrześcijanie na nowo doświadczyli tego, co było opisane w Dziejach Apostolskich: przychodzenia Ducha Świętego z mocą. Ten

$8 \quad$ Por. Jan Paweł II, Wierze w Ducha Świętego, Pana i Ożywiciela, Watykan 1992, s. 323. Jan Paweł II poświęca objawieniu Ducha Świętego, jako osoby, całą VI część katechez.

9 Por. F. Lambiasi, Lo Spirito Santo: mistero e presenza, Bologna 1991², s. 69; A. Jankowski, „Spiritus consummator" czyli ostateczne zadania Ducha Świętego, [w:] Napetnieni Duchem Świętym, pr. zb., Poznań 1982, s. 190-196.

10 Por. L. J. Suenens, Nowe Zesłanie Ducha Świętego?, s. 67.

11 Nie podejmujemy tu kwestii różnych form praktykowania duchowości charyzmatycznej, które są „ludzkimi” sposobami przeżywania darów. Za przykład może posłużyć bardzo zróżnicowane podejście do posługi w dziedzinie charyzmatów uzdrowienia. Tu różnice nie tylko wynikają z różnych praktyk modlitwy wstawienniczej, ale także z obecności różnych koncepcji antropologii i teologii łaski. Ten obszar domaga się jeszcze dogłębniejszych studiów, a także uporządkowania. W naszym studium chodzi o wprowadzenie pewnej metodologii, dzięki której dary Ducha Świętego nie będą odrzucane w wyniku przypisania im etykiety nadzwyczajności. 
fenomen nazwano „chrztem w Duchu”12. Zainteresowanie nim wynika z faktu, że po chrzcie w Duchu dokonuje się nagła i gruntowna przemiana osobowa oraz ujawniają się charyzmaty. Niemalże wszyscy liderzy wspólnot charyzmatycznych mogą poświadczyć, iż u początków przemiany ich życia znajduje się chrzest w Duchu Świętym. Tego daru doświadczają osoby, które wcześniej uczestniczyły w kursie przygotowawczym ${ }^{13}$, co potwierdzają towarzyszące mu fenomeny: dar języków, proroctwa, upadki w Duchu, dar łez i inne. W duchowości charyzmatycznej kluczowym terminem jest „doświadczenie” dotknięcia, namaszczenia czy wylania Ducha. Ktoś kto „miał doświadczenie”, odkrywa, że Duch Święty działa jako Osoba, jako ktośs ${ }^{14}$.

Warto też dodać, iż chrzest w Duchu Świętym występuje często w sposób bardziej ukryty i powolny, jednakże można rozpoznać jego skutki po zmianie w dziedzinie jakości modlitwy, odkryciu osobistej relacji miłości do Chrystusa, po wewnętrznym odblokowaniu na rozumienie Pisma Świętego, łatwości mówienia o swoje wierze, doświadczeniu radości z posiadania wiary, poczuciu głębokiej wdzięczności wobec Boga, jakie ma dziecko, odczuciu obecności Bożej i działania Ducha Świętego. Doświadczenie charyzmatyczne dostępne jest zarówno zmysłom duchowym, jak i zewnętrznym ${ }^{15}$.

Warto przytoczyć jeden z opisów wylania Ducha, dla dokonania później koniecznych rozróżnień. „Wylanie Ducha - według C. Massabkiego - oznacza w pierwszym rzędzie, iż Duch Święty, otrzymany w sakramentach chrztu i bierzmowania, zstępuje, by te sakramenty zaowocowały skuteczniej, dając równocześnie ich większą świadomość” ${ }^{16}$. Dlatego warto zauważyć za niektórymi autorami, iż „wylanie” odbywa się od wewnątrz (por. J 4, 14) ${ }^{17}$. Nie jest ono ani sakramentem ani rytem, lecz dostrzegalnym doświadczalnie momentem nawrócenia, pod wpływem wyraźnej interwencji Ducha Świętego, ale

12 Por. R. Cantalamessa, L'Effusione o battesimo nello Spirito? [w:] idem, La sobria ebrezza dello Spirito, wyd. 4, Roma 2013, s. 35-38. Termin „wylanie Ducha Świętego” używany chętniej przez katolików we Włoszech, Francji i Hiszpanii. W pozostałych krajach, również w Polsce, używa się nadal powszechnie nazwy „chrzest w Duchu Świętym”.

13 Por. „Cahiers du Renouveau“, 1984, nr 49, s. 34.

14 Por. H. Mühlen, Odnowa w Duchu Świętym. Wdrożenie w podstawowe doświadczenie chrześcijańskie, t. 1: Nauka i zachęta, tł. J. Zychowicz, Kraków 1985, s. 206.

15 Zob. P. L. Gavrilyuk, S. Coakley, Duchowe zmysty, tł. A. Gomola, Kraków 2014.

16 C. Massabki, Le Renouveau charismatique, une chance pour l'Église, Paris 1982, s. 23. Na temat powiązania owocności sakramentów z wiarą jest sporo literatury. Warto tu tylko nadmienić, iż zasada ex opere operato nie mówi o automatyzmie łaski w człowieku, lecz wskazuje na to, iż u podstaw sakramentu stoi decyzja Chrystusa, a nie wola człowieka. Łaska dlatego może trafić na opór w ludzkim sercu.

17 Por. A. Dalbesio, Duch Święty. W Nowym Testamencie, w Kościele, w życiu chrześcijańskim, Kraków 2001, s. 132. 
w następstwie modlitwy osobistej i wspólnotowej do Ducha Świętego, której towarzyszy gest nałożenia rąk, jako jedyny zewnętrzny znak solidarności i miłości z osobą omadlaną ${ }^{18}$.

Teologowie katoliccy poszukują nazwy adekwatniejszej dla określenia daru chrztu w Duchu Świętym, by nie przeciwstawiano błędnie tego daru, sakramentowi chrztu. W Polsce mimo tego najbardziej rozpowszechniona jest nadal nazwa „chrzest w Duchu Świętym”, dla zaznaczenia wyjątkowości owego wydarzenia Zstąpienia Ducha Świętego i towarzyszącego mu doświadczenia; chociaż można też mówić o wylaniu Ducha Świętego lub zstąpieniu ${ }^{19}$.

\section{Różne koncepcje chrztu w Duchu Świętym}

Istnieje kilka koncepcji interpretujących dar chrztu w Duchu Świętym, z których wymienimy cztery: dwustopniowa, sakramentalna, integratywna i odgórna. Ta prezentacja różnych koncepcji pozwoli nam dostrzec, iż chrzest w Duchu Świętym jest rzeczywistym działaniem Ducha Świętego, wokół którego narosło wiele interpretacji, osłabiających fakt epifanii Ducha Świętego.

Pierwsza, dwustopniowa wizja chrztu, występująca u zielonoświątkowców zakłada, że życie chrześcijanina ma strukturę dwupoziomową. Pierwszy stopień to nawrócenie/odrodzenie, czy ze względu na sakrament chrztu czy też na oddanie siebie Chrystusowi, drugi stopień to doświadczenie obecności Ducha, potwierdzone - choć nie wszyscy tak uważają - przez dar języków ${ }^{20}$. Teologowie katoliccy nie akceptują takiego poglądu, gdyż prowadzi on do błędnego wniosku, by za prawdziwych chrześcijan uważać tylko tych, którzy weszli na drugi poziom życia chrześcijańskiego, związanego z żywym doświadczeniem wylania Ducha Świętego ${ }^{21}$. Ponadto dla teologii katolickiej ważnym głosem jest głos mistyków, którzy - jak na przykład św. Jan od Krzyża - doświadczenie mistyczne Ducha łączą ze zjednoczeniem w miłości, a nie z charyzmatami języków czy proroctwa. To, co jest owocem wylania Ducha - drugie nawrócenie, przejawiające się w nowej jakości relacji z Chrystusem, ożywieniu wiary i modlitwy - jest dostępne ludziom zarówno po gwałtownym charyzmatycznym zstąpieniu Ducha, jak i po łagodnym, mistycznym wylaniu Ducha ${ }^{22}$.

18 C. Massabki, Le Renouveau charismatique, une chance pour l'Église, s. 23-30.

19 Por. A. Kuliberda, Weźmiecie w darze Ducha Świętego, t. 1, Częstochowa 2005, s. 56; P. W. Chlondowski, Chrzest w Duchu Świętym a sakramenty chrztu i bierzmowania, [w:] Duch Święty w naszej codzienności, K. Guzowski, G. Barth (red.), s. 187.

20 Por. J. Dunn, Baptism in the Holy Spirit, London 1970, s. 83-84.

21 Por. B. Gaybba, The Spirit of Love. Theology of the Holy Spirit, London 1987, s. 245.

22 Por. Karmelita Bosy, Duch Święty wyprowadza nas na pustynię, tł. M. J. Janecki, Kraków 2014, s. 54. 
Drugie ujęcie zwane jest sakramentalna interpretacją chrztu w Duchu. Zwolennicy tego ujęcia utrzymują, że chrzest w Duchu jest po prostu uwolnieniem łaski czy obecności, zaistniałej w wierzącym dzięki sakramentom inicjacji chrztu i bierzmowania. Z tego powodu wolą z oczywistych względów mówić o uwolnieniu, aniżeli o „chrzcie” w Duchu. Ta interpretacja zyskała spore grono zwolenników w Kościele katolickim²3. W 1974 odbyło się w Malines w Belgii międzynarodowe spotkanie, w trakcie którego przyjęto propozycję Kiliana McDonnell'a, by odróżniać znaczenie teologiczne i doświadczalne chrztu ${ }^{24}$. Teologicznie, chrzest w Duchu oznacza otrzymanie Ducha w chrzcie i bierzmowaniu, a doświadczalnie - to uświadomienie sobie obecności Ducha Świętego oraz Jego mocy w nas. Pod pewnymi warunkami może to być po prostu doświadczenie wzrostu w życiu chrześcijańskim ${ }^{25}$. Ta propozycja rozwiązuje problem dwustopniowości życia chrześcijańskiego, ale nie bierze pod uwagę kwestii elementów doświadczenia charyzmatycznego w postaci daru języków i innych fenomenów charyzmatycznych ${ }^{26}$. Mówienie o uwolnieniu dotąd „uśpionej” rzeczywistości nie znajduje potwierdzenia w doświadczeniu ludzi, którzy mówią o Rzeczywistości Osobowej, która niejako włamuje się w ich życie. Owo doświadczenie, nie wydaje się być uwolnieniem, ale przychodzeniem, które ma niezaprzeczalną nowośćc ${ }^{27}$.

Lepsze wydaje się ujęcie integratywne, które zakłada, że mogą występować nowe „zstąpienia” Ducha na wierzącego, poza początkowym przyjściem. Jednakże owo przychodzenie Ducha nie powinno być rozumiane jako przychodzenie spoza osoby, skoro Duch Święty już zamieszkuje w wierzącym. Mamy do czynienia jedynie z nowym aspektem tej obecności, która skutkuje doświadczeniem czegoś nowego w życiu wierzącego ${ }^{28}$. W tej koncepcji istotne jest przywrócenie wymiaru teologicznego, który został pominięty w interpretacji sakramentalnej chrztu w Duchu Świętym. Chrzest w Duchu jest nie tylko doświadczalnie, lecz również teologicznie czymś odrębnym od namaszczenia Duchem Świętym w sakramentach inicjacji. Obie teorie łączy idea zamieszkiwania (inhabitatio) Ducha w wierzącym. Nowe zesłanie nie jest nową obecnością, ale

23 Por. H. I. Lederle, The Charismatic Movement - the ambiguous challenge, „Missionalia” 14 (2) 1986, s. 75. Ta koncepcja została przyjęta w dokumentach z Malines, ale trudno uznać ją za oficjalną w Kościele katolickim.

Por. F. A. Sullivan, Charyzmaty $i$ Odnowa Charyzmatyczna. Studium biblijne i teologiczne, tł. T. M. Micewicz, Warszawa 1992, s. 54.

25 Por. K. McDonnell, Presence, Power, Praise. Documents on the Charismatic Renewal, New York 1980, s. 39-40.

26 Por. F. A. Sullivan, Charyzmaty i Odnowa Charyzmatyczna, s. 57.

27 B. Gaybba, The Spirit of Love, s. 248.

28 Por. F. A. Sullivan, Charyzmaty $i$ Odnowa Charyzmatyczna, s. $61 \mathrm{n}$. 
nowym wymiarem zamieszkujacej obecności. To podejście integratywne znalazło aprobatę również wśród teologów niekatolickich. Chodzi bowiem o to, że w tym ujęciu doświadczenie charyzmatyczne jest w pełni zintegrowane z normalnym chrześcijaństwem, a sam chrzest w Duchu jest widziany jako nowe przyjście Ducha, wzmożone doświadczenie Boga lub jako duchowy przełom. Unika się tutaj elitaryzmu w podejściu do charyzmatycznego wymiaru życia ${ }^{29}$.

Oczywiście to trzecie, integratywne podejście umożliwia stosowanie określenia „chrzest w Duchu” do wielu wydarzeń w życiu chrześcijanina, a zatem do każdego punktu zwrotnego, zmieniającego osobisty stosunek do Chrystusa. Odnosi się również do wzrostu duchowego, nawet jeśli jest dostrzegalny dopiero po czasie, co więcej - jest powtarzalne. Osoba może doświadczyć kilku punktów zwrotnych ${ }^{30}$. Jednak i ta koncepcja nie bierze pod uwagę prostego faktu, iż chrzest w Duchu Świętym jest wydarzeniem niepowtarzalnym, rodzajem przełomu, który zmienia radykalnie relację do Boga. Chrzest w Duchu Świętym jest nowym początkiem życia i przyjaźni z Bogiem, i bramą dla ujawnienia się charyzmatów. To pierwsze wylanie Ducha zwykle związane jest $z$ darem języków.

Dla usunięcia owego cienia nadzwyczajności i elitaryzmu, wyłaniających się $z$ trzech omówionych koncepcji chrztu w Duchu Świętym, pragnę zaproponować ujęcie odgóme, które posiada odmienny punkt wyjścia od poprzednich. Tamte przyjmowały za punkt wyjścia określony schemat strukturalny: sakramentalny lub charyzmatyczny. W tej koncepcji przyjmujemy za punkt wyjścia odgórną perspektywę ekonomii Trzech Osób Bożych, którą cechuje osobowe działanie: Ojciec objawia się przez Syna w Duchu Świętym! ${ }^{31}$ Bóg Trójjedyny nie działa nigdy w sposób bezosobowy, a Jego dary są przejawami jego Miłości. Za św. Pawłem przyjmujemy dwie typowe ścieżki działania Ducha Świętego: działanie charyzmatyczne i uświęcające, $z$ których pierwsze jest objawieniem Ducha pełnego mocy, a drugie wyraża się w owocach życia przebóstwionego i nowego. Jednakże jedno i drugie działanie należy do wszechogarniającej perspektywy trynitarnej, zgodnie $z$ tym, co powiedział na ten temat Benedykt XVI:

29 Por. H. I. Lederle, The Charismatic Movement - the ambiguos challenge, s. 65.

30 Por. F. A. Sullivan, Charyzmaty $i$ Odnowa Charyzmatyczna, s. 65. Sullivan uważa, że ludzie powinni modlić się o „nowe wylania” Ducha lub o „kolejny chrzest z Ducha” czy też o to, by Duch napełnił kogoś na nowo.

31 Pomijamy ze względów formalnych przebogaty materiał dotyczący problematyki zamieszkiwania Osób Trójcy Świętej w duszy człowieka, oraz posłannictw wewnątrztrynitarnych. Kwestię inhabitatio omawia publikacja amerykańskiego autora W. R. O'Connora, dostępna w wersji elektronicznej na stronie czasopisma „Proceedings”. Tytuł opracowania: The inhabitation of the Holy Spirit. 
„Jezus jest tym, który przyszedł, żeby ochrzcić ludzkość w Duchu Świętym”32. Zgodnie z biblijnym znaczeniem „chrzcić”, oznacza napełniać, zanurzać w Duchu, a jest to zawsze działanie konkretne i uświęcające.

Chrzest w Duchu Świętym jako jeden z wielu darów Bożej Miłości, posiada jednak swoją specyfikę: jest to ujawnianie się mocy Ducha Świętego, którego owocem jest przede wszystkim obudzenie lub umocnienie wiary w bliską, namacalną i osobową obecność Boga, podczas gdy wcześniej obecność Boża była enigmatyczna i niewyczuwalna. Z tego powodu doświadczenie chrztu w Duchu Świętym staje się momentem przełomowym dla wiary i osobistej relacji z Chrystusem. Dzięki temu darowi następuje odkrycie, że Pięćdziesiątnica nie jest faktem zamierzchłej przeszłości, lecz nieustanną obecnością Boga w nas i w naszej historii. To wówczas - gdy wiara $z$ absencyjnej i ogólnej staje się wiara w realną Obecność - następuje odblokowanie łaski chrztu i bierzmowania. Z tej to przyczyny chrzest w Duchu Świętym nie jest zjawiskiem marginalnym w życiu chrześcijanina, ani nie może być przeciwstawiany sakramentom chrztu czy bierzmowania. Duch Święty uzdalnia chrześcijanina w sakramentach inicjacji „do przyobleczenia «umysłu Chrystusowego» - by myślał jak On i kochał jak On (Rz 13, 14; 1 Kor 2, 16; Flp 2, 5) i takim sposobem dokonywał dzieł, których On dokonywał $(\mathrm{J} 14,12){ }^{\prime 33}$, natomiast po chrzcie w Duchu Świętym następuje „rozpalenie na nowo” daru już otrzymanego (por. $2 \mathrm{Tm}$ 1, 6). Chodzi o to, że wraz z darem chrztu w Duchu Świętym nowe narodzenie i Boże życie, otrzymane w sakramentach inicjacji, stają się rzeczywistością osobistą, której się doświadcza. To z kolei prowadzi do zwycięstwa nad grzechem, władzy nad podstępami złego oraz wzrostu w cnocie przez zjednoczenie ze zmartwychwstałym Jezusem ${ }^{34}$.

Jeśli spoglądamy na dar chrztu w Duchu Świętym odgórnie, to dostrzeżemy dynamizm i rozwój życia ludzkiego - wszczepionego uprzednio w Boga (!) przez sakramenty inicjacji. Chrzest w Duchu Świętym jest po pierwsze objawieniem miłosnej obecności Ojca, Syna i Ducha Świętego, a po drugie jest początkiem poddania i prowadzenia przez Ducha Świętego (por. Rz 8, 14) w wyniku objawienia się Jego działania i mocy. Bywa też określany jako nowe nawrócenie lub przebudzenie.

Perspektywa odgórna pozwala dostrzec linię ciągłości pomiędzy działaniem uświęcającym i charyzmatycznym Ducha Świętego. W jednym i drugim przypadku czynnikiem łączącym jest miłość Boża, która objawia się nam jako

32 Rozważanie przed modlitwa Aniol Pański, Święto Chrztu Pańskiego, 13 stycznia 2008. Cyt. za ICCRS, Chrzest w Duchu Świętym, s. 58.

33 ICCRS, Chrzest w Duchu Świętym, s. 59.

34 Ibidem. 
Osoba Ducha Świętego. Miłość jest cechą typową objawiania się Ducha Świętego, dlatego zarówno Augustyn, jak i Tomasz, wiążą ściśle posiadanie miłości z „posiadaniem” Ducha Świętego, a raczej z owocami Jego przemieniającej obecności. W tym kontekście należy stwierdzić, że „Być ochrzczonym Duchem Świętym, to być napełnionym miłością, która na wieki przepływa pomiędzy Ojcem i Synem w Trójcy Świętej; miłością, która przemienia ludzi na najgłębszym poziomie ich jestestwa [...] i sprawia, że stają się zdolni w zamian pokochać Boga" ${ }^{35}$. Pod wpływem daru chrztu ludzie poznają „miłość Chrystusa, przewyższającą wszelką wiedzę" (Ef 3, 18-19).

Wymienione cztery koncepcje chrztu w Duchu Świętym: zielonoświątkowa, sakramentalna, integratywna i odgórna pozwalają nam dostrzec powiązanie różnych aspektów tego daru z zesłaniem Ducha Świętego w dzień Pięćdziesiątnicy i Jego nieustanną obecnością. Wniosek nasuwa się głównie jeden: chociaż chrzest w Duchu Świętym nie jest darem koniecznym do Zbawienia, ani wyższym od łaski udzielonej w sakramencie chrztu lub bierzmowania, to jednak powinien być przyjmowany z wdzięcznością, jako charyzmat wiary. Katolicy nie muszą powielać całego szeregu form praktyk modlitewnych i nabożeństw obecnych w kościołach zielonoświątkowych czy wspólnotach charyzmatycznych, lecz powinni w czasach naznaczonych zanikaniem wiary i widzialnych struktur Kościoła w wielu krajach, przyjąć ten dar intensyfikując wołanie do Ducha Świętego o ratunek i Jego panowanie.

Chrystus namaścił mocą i ogniem Ducha Świętego cały Kościół, aby jego członkowie umocnieni charyzmatami, przewodzili owczarni jako pasterze, głosili słowo zbawienia i wyzwolenia jako nauczyciele i prorocy. Fenomen „wzmożonej aktywności" Ducha Świętego w świecie współczesnym powinien być doceniony, jako najważniejszy znak czasu. Odnowa Charyzmatyczna przyjęła ten dar jako pierwsza, ale jest to dar dla całego Kościoła.

\section{Gdzie Duch Święty - tam modlitwa}

Powiązanie aktualności Pięćdziesiątnicy z modlitwą kontemplacyjną, to drugi ważny element ożywienia wiary w stałą i powszechna obecność Ducha Świętego w codzienności. Po liczbie stowarzyszeń i wspólnot propagujących modlitwę kontemplacyjną oraz tzw. medytację głębi, a także po liczbie publikacji na temat modlitwy chrześcijańskiej - można z pewnością stwierdzić, że jest to jeden z ważniejszych znaków „wzmożonej aktywności” Ducha Świętego, którą zwykło się nazywać już powszechnie: Nową Pięćdziesiątnicą. Jan Paweł II przypomniał w encyklice Dominum et Vivificantem decydującą rolę Ducha Świętego w dziele modlitwy:

35 ICCRS, Chrzest w Duchu Świętym, s. 58. 
Duch Święty jest darem, który przychodzi do serca ludzkiego wraz z modlitwa. W modlitwie objawia się On przede wszystkim jako Dar, „przychodzi bowiem z pomocą naszej słabości”. Święty Paweł rozwija wspaniale tę myśl w Liście do Rzymian $(8,26)$. (...) Tak więc Duch Święty nie tylko sprawia, że się modlimy, ale prowadzi nas wewnętrznie na modlitwie, uzupełniając naszą nieumiejętność modlenia się" ${ }^{36}$.

Papież mówi wprost o objawieniowej i przebóstwiającej roli modlitwy, która jest znakiem obecności osoby Ducha Świętego i znakiem trwania dzieła Pięćdziesiątnicy:

Chociaż jest faktem historycznym, że Kościół wyszedł z Wieczernika w dniu Pięćdziesiątnicy, to równocześnie można powiedzieć, że nigdy go nie opuścił. W sensie duchowym wydarzenia Zielonych Świąt nie można zaliczać tylko do przeszłości: Kościół jest zawsze obecny w Wieczerniku i nosi go w sercu. Trwa na modlitwie, podobnie jak trwali na modlitwie Apostołowie wraz z Maryja, Matką Chrystusa oraz tymi, którzy stanowili w Jerozolimie pierwszy zalążek wspólnoty chrześcijańskiej i modląc się oczekiwali przyjścia Ducha Świętego ${ }^{37}$.

Analogicznie do tej prawdy o Pięćdziesiątnicy jako nieustannym działaniu Chrystusa w świecie poprzez osobę Ducha Świętego, Jan Paweł II wyjaśnia specyfikę chrześcijańskiego rozumienia modlitwy, która jest „tchnieniem” Ducha Świętego, a zatem Jego dziełem, a nie - jak się nierzadko mniema aktywnością człowieka:

Piękna i zbawienna jest myśl, że jak szeroko rozprzestrzenia się modlitwa na całym okręgu ziemi, w przeszłości, teraźniejszości i przyszłości, tak rozległa jest obecność i działanie Ducha Świętego, który „tchnie” modlitwę w serce człowieka w całej niezmierzonej gamie różnych sytuacji i warunków, raz sprzyjających, raz przeciwnych życiu duchowemu i religijnemu. (...) Piękna i zbawienna jest myśl, że gdziekolwiek ktoś modli się na świecie, tam jest Duch Święty, ożywcze tchnienie modlitwy ${ }^{38}$.

Modlitwa w jej wymiarze kontemplacyjnym, jako uczestniczenie w życiu Boga za sprawą Ducha Świętego stanowi istotny czynnik dojrzewania nowego człowieka. Nowy człowiek to ten, który czerpie życie z Trójcy, a nie z siebie ${ }^{39}$. Z tego względu modlitwa chrześcijańska jako dzieło Ducha Świętego w duszy człowieka - jako Jego tchnienie - ma moc uświęcania i przebóstwiania wszystkich wymiarów ludzkiego stworzonego życia.

Warto też nadmienić, że modlitwa chrześcijańska jest zjawiskiem nieporównywalnym do praktyk modlitewnych, obecnych w innych religiach. Tę inność widać już w Starym Testamencie. Na etapie, gdy nie istniało jeszcze

\footnotetext{
36 DeV 65. Podkreślenia według tekstu oryginalnego.

$37 \quad \mathrm{DeV} 66$.

$38 \mathrm{DeV} 65$.

$39 \mathrm{DeV} 65$.
} 
pojęcie „modlitwy”, łączność ludu Izraela z Bogiem opierała się na wierze w Jego wszechobecność, w to, że człowiek i świat jest przeniknięty Duchem Bożym jak powietrzem, a „modlić się” znaczyło według prostej podstawowej formuły tyle: co akceptować bliskość, wierzyć że Bóg jest ze mną, przebywać w Bożej wszechobecności (Rdz 5, 24; 6, 9; 17, 1). To wszechobecność Boga była powodem, że Go spotykano, że widziano w przyrodzie Jego mądrość i znaki dobroci. Psalmista pisał: „Ty ogarniasz mnie zewsząd i kładziesz na mnie swą rękę. [...]. Gdzież oddalę się od Twojego Ducha? Gdzie ucieknę od Twego oblicza?" (Ps 139, 5.7) ${ }^{40}$.

W Nowym Testamencie prawda o wszechobecności Ducha Świętego jest fundamentalna dla dziedziny modlitwy. Nie chodzi o to, by Boga upraszać o interwencję, lecz by uznać Jego obecność i wychwalać za to, co dla nas już czyni. Jednym słowem, modlitwa jest aktualizacją wiary w powszechną obecność Ducha Chrystusowego, który jest w nas obecny realnie jako Osoba. Świadectwa Nowego Testamentu mówią wyraźnie o tym, że modlitwa jest specyficznym dziełem Pocieszyciela: my modlimy się w Duchu Świętym (por. $\mathrm{J} 4,21-24)$, a raczej to Duch modli się w nas (Rz 8, 26n), gdyż tylko Duch Syna ma moc poderwać naszego ducha do wysławiania Boga jako Ojca (Rz 8, 15; Ga 4, 6). Duch Święty sprawia, że wewnętrznie odczuwamy bliskość Boga, jakiej doświadczał Jezus, jako Syn. Do miłości nie jest w stanie nas nikt skłonić, ale Duch daje nam zdolność kochania Boga jako Ojca, kształtując w nas ducha synowskiego ${ }^{41}$.

W temacie modlitwy św. Paweł określa rolę Ducha Świętego mianem wstawiennictwa. Interesujący nas temat wstawiennictwa był w przeszłości interpretowany w sposób błędny przez Macedoniusza (IV w.), który był przekonany o tym, jakoby Duch Święty był niżej stojącym od Boga pośrednikiem pomiędzy Nim a ludźmi ${ }^{42}$. Biblia Tysiąclecia używa zwrotu „przyczynia się”, unikając $w$ ten sposób skojarzenia z podobną rolą Maryi i świętych, którzy wstawiają się za nami u Boga. O wyjątkowości tego działania Ducha Świętego, św. Paweł pisze znamienne słowa: „Podobnie także Duch przychodzi z pomocą naszej słabości. Gdy bowiem nie umiemy się modlić tak, jak trzeba, sam Duch przyczynia się za nami w błaganiach, których nie można wyrazić słowami. Ten zaś, który przenika serca, zna zamiar Ducha, [wie], że przyczynia się za świętymi zgodnie z wolą Bożą" (Rz 8, 26-27).

Wstawiennictwo Ducha Świętego nie dokonuje się ani pomiędzy Bogiem a człowiekiem, ani też w imieniu człowieka przed Bogiem. To właśnie

40 Por. A. Läpple, Powróćmy do modlitwy, tł. J. Zychowicz, Kraków 1991, s. 80-82.

41 Por. K. Guzowski, Duch dialogujący. Zarys pneumatologii dialogalnej, Lublin 2016, s. 335-339.

42 Por. L. S. Chafer, Pneumatology. Systematic Theology, t. 6, Dallas 1967, s. 43. 
zamieszkiwanie Ducha Świętego w nas sprawia, iż Bóg nas „przenika” i zna, jak czytamy u św. Pawła: „Ten zaś, który przenika serca, zna zamiar Ducha, [wie], że przyczynia się za świętymi zgodnie z wolą Bożą” (Rz 8, 27). Bóg „przenika serca", by dowiedzieć się, jaki jest zamysł zamieszkującego Ducha Świętego odnośnie chrześcijanina (świętego), by mógł z kolei dostarczyć mu tego, czego on potrzebuje. Bowiem w dziele Zbawienia, wszelkie pośrednictwo i łączność między Bogiem i stworzeniami dokonuje się z udziałem Ducha Świętego. Boży Duch mieszkający w nas, znający nasze zamiary lepiej niż my, sam błaga w naszych modlitwach, podnosząc nas ku wyższym i świętszym pragnieniom niż te, które możemy wyrazić słowami. Ta Boża pomoc dla prawidłowej i skutecznej praktyki modlitwy powinna być przyjęta jako przywilej i dar, jaki uzyskuje każde dziecko Boże, które w chrzcie otrzymuje namaszczenie Duchem ${ }^{43}$.

W Psalmie 139 znajdziemy wyjaśnienie, że modlitwa w Duchu odbywa się o wiele głębiej niż na poziomie werbalizacji i rodzi się z daru obecności: „Panie przenikasz i znasz mnie, Ty wiesz, kiedy siedzę i wstaję. Z daleka przenikasz moje zamysły, widzisz moje działanie i mój spoczynek i wszystkie moje drogi są Ci znane. Choć jeszcze nie ma słowa na moim języku, Ty Panie już znasz je w całości (...) Gdzież odejdę daleko od Twego ducha?" (Ps 139, 1-7). Zatem to nie modlitwa „woła” do Boga, lecz nasz duch przepojony i uświęcony tchnieniem Ducha Świętego. Analogicznie łaska wiary daje nam głębsze zrozumienie mowy Boga, niż jesteśmy w stanie wyrazić to słowami.

Prawdziwy sens modlitwy polega na zjednoczeniu duszy z Bogiem, a jedność z Nim i spotykanie Go jest zawsze darem Ducha Świętego. Zatem modlitwa może „przyjść” jak każdy dar Boga przez otwarcie na Ducha Świętego, który nas jednoczy z Ojcem przez Syna: „Modlitwa chrześcijańska jest związkiem przymierza między Bogiem i człowiekiem w Chrystusie. Jest działaniem Boga i człowieka; wypływa z Ducha Świętego i z nas, jest skierowana całkowicie ku Ojcu w zjednoczeniu z ludzką wolą Syna Bożego, który stał się człowiekiem”"44. W tym sensie człowiek może wypowiadać słowa, ale nie „modlić się”. Z tego względu modlitwa chrześcijańska z natury jest modlitwą kontemplacyjną, skoncentrowaną na obecności Ducha. Jan Damasceński jest przekonany, że „Życie modlitwy polega na stałym trwaniu w obecności trzykroć świętego Boga w komunii z Nim. (...) Jest wzniesieniem duszy do Boga" ${ }^{\prime 4}$. Z tego powodu praktyka modlitwy kontemplacyjnej skupionej na obecności Pana i na Jego Osobie, wyraża się w milczącej uwadze, serdecznej miłości oraz adoracji.

43 Por. K. Guzowski, Duch dialogujacy, s. 112.

44 KKK 2564. Por. Petna jest ziemia Twego Ducha, Panie. Oficjalny dokument Komisji Teologiczno-Historycznej Wielkiego Jubileuszu Roku 2000, Katowice 1997, s. 154-155.

45 O prawdziwej wierze III, 24. Cyt. za KKK 2565. 
Mistrzowie modlitwy dlatego zwracają uwagę, iż na etapie modlitwy kontemplacyjnej zbyteczne okazują się słowa, bodźce zewnętrzne i emocje; uwaga duszy koncentruje się na tej Obecności. Rozwój zainteresowania modlitwą kontemplacyjną wśród charyzmatyków spowodowal, iż zostały połączone ze sobą dwa elementy nieprzystawalne do siebie w duchowości ruchu zielonoświątkowego utożsamianego z głośnym uwielbieniem: milczenia oraz modlitwy w Duchu Świętym.

Ten cichy sposób przychodzenia i tchnienia Ducha Świętego, które stanowi modlitwę, powinien pociągać tych, którym obca jest głośna i swobodna modlitwa charyzmatyczna w językach.

\section{Zakończenie}

Odnowa Charyzmatyczna zwróciła uwagę na aktualność daru Pięćdziesiątnicy, doświadczając jej owoców we współczesnym czasie. Dar ten wyraża się w stałej obecności Boga przez Ducha i dynamice dzieła Zbawienia, którego kontynuatorem i realizatorem jest Pocieszyciel, mieszkający w człowieku. Duch Święty zaznacza nieustannie swoją obecność w Kościele i w osobach, które On jednoczy w Kościól. Jedne znaki Jego obecności można rozpoznać oczami wiary, jako twórcy wspólnoty Kościoła i mieszkańca duszy; inne są wydarzeniami budzącymi wiarę w Jego obecność, dzięki temu że dotykają naszych zmysłów zewnętrznych i wyprowadzają naszego ducha z uśpienia.

W niniejszym artykule zmierzyliśmy się z problemem przypisywania cechy nadzwyczajności wszystkim przejawom mocy Ducha, wśród których szczególnie umieszcza się zjawiska charyzmatyczne. To sprawiło, iż wiara w Ducha Świętego jako Ożywiciela, Dawcę nowego życia, i Boga bliskiego nie przedostaje się do krwioobiegu Kościoła i zwyczajnej posługi duszpasterskiej kapłanów. Dzięki zestawieniu dwóch bardzo różnych od siebie form objawiania się Ducha oraz różnych poziomów doświadczenia jego Obecności, w połączeniu z teologią Pięćdziesiątnicy - mogliśmy zobaczyć, iż kategorie „zwyczajny” i „nadzwyczajny” są nieadekwatne do opisu epifanii Ducha. Zarówno chrzest w Duchu Świętym jako przejaw mocy i obecności Ducha Świętego, jak i modlitwa kontemplacyjna, która jest owocem cichego tchnienia Ducha w duszy człowieka, mówią o różnorodności form ekonomii Ducha. Ów łagodny sposób przychodzenia i tchnienia Ducha Świętego, które stanowi modlitwę, powinien pociągać tych, którzy nie uznają głośnej i wzniosłej modlitwy charyzmatycznej w językach.

Święty Łukasz ukazuje w Dziejach Apostolskich działanie Ducha jako fundament nowego kultu, a tym samym - modlitwy. Tylko 18 razy opis działania Ducha Świętego odnosi się do Jego nadzwyczajnych pojawień, natomiast w 36 przypadkach chodzi o porządek zwyczajny i codzienny, o działanie stałe 
i regularne. W doświadczeniu ewangelisty działanie Ducha Świętego nie jest ograniczone do chwilowych i nadzwyczajnych manifestacji, lecz dotyczy całej wspólnoty, chociaż już sama obecność i działanie Ducha Świętego jest dla Łukasza czymś niezwykłym.

Duch Święty jest ponadwyznaniowy i ponadczasowy, a równocześnie konkretnie obecny w Chrystusie, w świętych i w dziełach, które tworzy w Kościele i poza nim. Nie jesteśmy w stanie wyczerpać prawdy o Duchu Świętym zatrzymując się na progu banalnych wyobrażeń lub określając zaledwie typowe loci Jego przebywania lub aktywności. Prawdziwe okazują się jedynie te twierdzenia, które nie zawężają sprawy obecności i działania Ducha Świętego w świecie, do wyjątkowych zdarzeń.

Przed 50 laty, gdy ruch charyzmatyczny zaczął się rozwijać, widziano w nim jeden z ważniejszych znaków Nowej Pięćdziesiątnicy, czyli wzmożonego działania Ducha Świętego w naszych czasach. Paweł VI i kolejni papieże wskazywali na ową „wzmożoną aktywność” Ducha Świętego, oraz na Niego jako jedynego Odnowiciela Kościoła i źródło nowego życia dla świata. Niestety owa potężna obecność, a zarazem wzmożona aktywność Ducha Świętego w Kościele, została przysłonięta z jednej strony przez nadmierne skoncentrowanie członków tego ruchu na tym, co zaspokaja przede wszystkim potrzeby ludzi, jak: uzdrowienia czy nadzwyczajne fenomeny, a $z$ drugiej przez nadmierny sceptycyzm teologów i duszpasterzy, którzy przez 50 lat istnienia Odnowy nie wspierali dostatecznie swą refleksją teologiczną wiernych, niezdolnych odróżnić istoty od spraw nadzwyczajnych. Należy wyraźnie stwierdzić, że kategorie „zwyczajny” i „nadzwyczajny" w odniesieniu do Nowej Pięćdziesiątnicy, niczego nie porządkują, lecz utrudniają samą refleksję teologiczną, gdyż są kategoriami subiektywnymi. Dlatego należy skoncentrować się na rozróżnianiu tego, co jest darem Ducha Świętego, a co wytworem człowieka. Skoncentrowanie się na osobie Ducha Świętego i Jego dziele uświęcającym, pozwala odróżnić to, co istotne w Nowej Pięćdziesiątnicy od spraw drugorzędnych.

Słowa kluczowe: Duch Święty, Nowa Pięćdziesiątnica, ruch Odnowy Charyzmatycznej, chrzest w Duchu Świętym, modlitwa kontemplacyjna, zwyczajny, nadzwyczajny.

\section{Bibliografia:}

1. Brown R. E., Azione e promessa dello Spirito a Pentecoste, Brescia 1995.

2. Cantalamessa R., Tajemnica Pięćdziesiątnicy, tł. G. Niedźwiedź, Wrocław 2002.

3. Cantalamessa R., La sobria ebrezza dello Spirito, Roma $2013^{4}$. 
4. Carter E., Duch Święty jest obecny. Rozważania o duchowości chrześcijańskiej, t1. A. Korlińska, Warszawa 1975.

5. Chafer L. S., Pneumatology. Systematic Theology, t. 6, Dallas $1967^{8}$.

6. Chlondowski P. W., Chrzest w Duchu Świętym a sakramenty chrztu i bierzmowania, [w:] Duch Święty w naszej codzienności, K. Guzowski, G. Barth (red.), Lublin 2010.

7. Congar Y., Wierzę w Ducha Świętego, t. 2, t1. L. Rutowska, Warszawa 1995.

8. Dalbesio A., Duch Święty. W Nowym Testamencie, w Kościele, w życiu chrześcijańskim, Kraków 2001.

9. Del Colle R., The Holy Spirit: Presence, power, person, „Theological Studies” 62(2001), s. 322-340.

10. Dunn J., Baptism in the Holy Spirit, London 1970.

11. Gaybba B., The Spirit of Love. Theology of the Holy Spirit, London 1987.

12. Gavrilyuk P. L., Coakley S., Duchowe zmysty, tł. A. Gomola, Kraków 2014.

13. Guzowski K., Duch dialogujacy. Zarys pneumatologii dialogalnej, Lublin 2016.

14. Hocken P., Pięćdziesiątnica i Paruzja, tł. A. Sionek, Kraków 2015.

15. Jankowski A., ,Spiritus consummator” czyli ostateczne zadania Ducha Świętego, [w:] Napetnieni Duchem Świętym, pr. zb., Poznań 1982, s. 190-202.

16. Jankowski A., Duch Święty Dokonawca zbawienia, Kraków 2003.

17. Jan Paweł II, Encyklika Dominum et Vivificantem, Watykan 1986.

18. Jan Paweł II, Wierzę w Ducha Świętego, Pana i Ożywiciela, Watykan 1992.

19. Karmelita Bosy, Duch Święty wyprowadza nas na pustynię, tł. M. J. Janecki, Kraków 2014.

20. Kuliberda A., Weśmiecie w darze Ducha Świętego, t. 1, Częstochowa 2005.

21. Lambiasi F., Lo Spirito Santo: mistero e presenza. Per una sintesi di pneumatologia, Bologna $1991^{2}$.

22. Läpple A., Powróćmy do modlitwy, tł. J. Zychowicz, Kraków 1991.

23. Lederle H. I., The Charismatic Movement - the ambiguous challenge, „Missionalia” 14 (2) 1986, s. 61-75.

24. Massabki C., Le Renouveau charismatique, une chance pour l'Église, Paris 1982.

25. McDonnell K., Presence, Power, Praise. Documents on the Charismatic Renewal, New York 1980.

26. Mühlen H., Odnowa w Duchu Świętym. Wdrożenie w podstawowe doświadczenie chrześcijańskie, t. 1: Nauka i zachęta, tł. J. Zychowicz, Kraków 1985.

27. Örsy L. M., Otwarcie się na Ducha, tł. T. Marcinkowska, Warszawa 1976.

28. Petna jest ziemia Twego Ducha, Panie. Oficjalny dokument Komisji Teologiczno-Historycznej Wielkiego Jubileuszu Roku 2000, Katowice 1997.

29. Sullivan F. A., Charyzmaty i Odnowa Charyzmatyczna. Studium biblijne i teologiczne, tł. T. M. Micewicz, Warszawa 1992.

30. Suenens L. J., Nowe Zestanie Ducha Świętego? tł. J. Fenrychowa, Poznań 1988. 